\title{
Vulvar Syringoma in a Premenopausal Woman: A Case Report
}

\author{
Premenopozal Bir Kadında Vulvar Siringoma: Olgu Sunumu
}

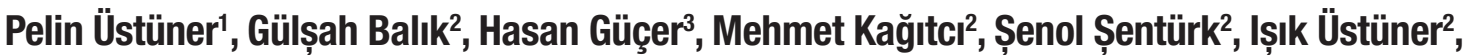 Emine Seda Güvendağ Güven²}

${ }^{1}$ Dermatology Clinic, Rize State Hospital, Rize, Turkey; ${ }^{2}$ Department of Obstetrics and Gynecology, Recep Tayyip Erdoğan University School of Medicine, Rize, Turkey; ${ }^{3}$ Department of Pathology, Recep Tayyip Erdoğan University School of Medicine, Rize, Turkey

\begin{abstract}
A wide spectrum of benign, premalignant, and malignant lesions may involve the vulva. The challenge facing the clinician is to differentiate normal variants, benign findings, and potentially serious diseases, and this is not always easy. Syringomas are benign neoplasms of the eccrine sweat glands. They commonly occur in the lower eyelid and upper malar areas, appearing less frequently in the upper lip, axillae, extremities, buttocks, chest, abdomen, or thigh with the involvement of the vulva being rare. These lesions most often found in women around the time of adolescence. In this paper we present an incidentally diagnosed vulvar syringoma in a 47-year old female without any involvement of other parts of the body. Due to their clinical presentation and associated symptoms, vulvar syringomas should be considered in the differential diagnosis of any flesh colored or non-pigmented papules and nodules of the vulva, vulvar pain syndrome, and pruritus vulva.
\end{abstract}

Key words: neoplasms; sweat glands; syringoma; vulva

\section{ÖZET}

Benign, premalign ve malign lezyonların geniș bir spektrumu vulvayı tutabilmektedir. Klinisyenin karșılaștığı sıkıntı normal varyantlar, benign bulgular ve potansiyel tehlikeli hastalıkları ayırt edebilmektir ve bu her zaman kolay değildir. Siringomalar ekrin ter bezlerinin benign neoplazileridir. Siringomalar sıklıkla alt göz kapağında ve yukarı malar bölgelerde görülmekte, daha az sıklıkta yukarı dudak, aksilla, ekstremiteler, kalçalar, gögüs veya karında olup vulva tutulumu nadirdir. Bu lezyonlar sıklıkla adolesan dönemine yakın kadınlarda görülür. Bu yazıda diğer vücut alanlarının tutulumu olmaksızın 47 yașındaki bir kadında tesadüfen tanı almıș bir vulvar siringoma olgusunu sunduk. Klinik prezentasyonları ve ilișkili semptomları gereği, vulvar siringomalar vulvanın herhangi bir șeffaf renkli veya pigmente olmayan papül ya da nodüllerinin, vulvar ağrı sendromunun ve vulvar pruritusun ayırıcı tanısında ele alınmalıdır.

Anahtar kelimeler: neoplaziler; ter bezleri; siringom; vulva

Uzm. Dr. Pelin Üstüner, Rize State Hospital, Dermatology Clinic, Eminettin Mahallesi, Rize, Türkiye Tel.05052520223 Email.pelindogaustuner@gmail.com Geliş Taribi: 31.01.2014 • Kabul Taribi: 17.10.2015

\section{Introduction}

A wide spectrum of benign, premalignant, and malignant lesions may involve the vulva. The challenge for the clinician is to differentiate normal variants, benign findings, and potentially serious diseases, and this is not always easy.

Syringomas are benign neoplasms of the eccrine sweat glands. They commonly occur in the lower eyelid and upper malar areas, appearing less frequently in the upper lip, axillae, extremities, buttocks, chest, abdomen, or thigh with the involvement of the vulva being rare $\mathrm{e}^{1,2}$. Vulvar syringomas typically present as multiple, one to two $\mathrm{mm}$, flesh-colored to yellow papules arranged bilateral and symmetrical on the major labia, however solitary lesions have also been reported ${ }^{1,3}$. Simultaneous involvement of the peri-orbital skin, cheeks or neck is common. Most lesions are non-regressing and asymptomatic, but in contrast to lesions elsewhere, heat and sweating, menstruation, or pregnancy may provoke pruritus in vulvar syringomas ${ }^{4,5}$. The occurrence of syringoma is twice more common in women than men, with adolescence being the most common time of onset ${ }^{1}$.

In this paper, we present an incidentally diagnosed vulvar syringoma case without any involvement of other body sites in a 47 -year old female.

\section{Case Report}

A 47-year old, multiparous patient was admitted our clinic with a complaint of menorrhagia and urinary incontinence refractory to medical treatment.

On the dermatological examination; multiple, fleshcolored, millimetric papules were seen on the right 


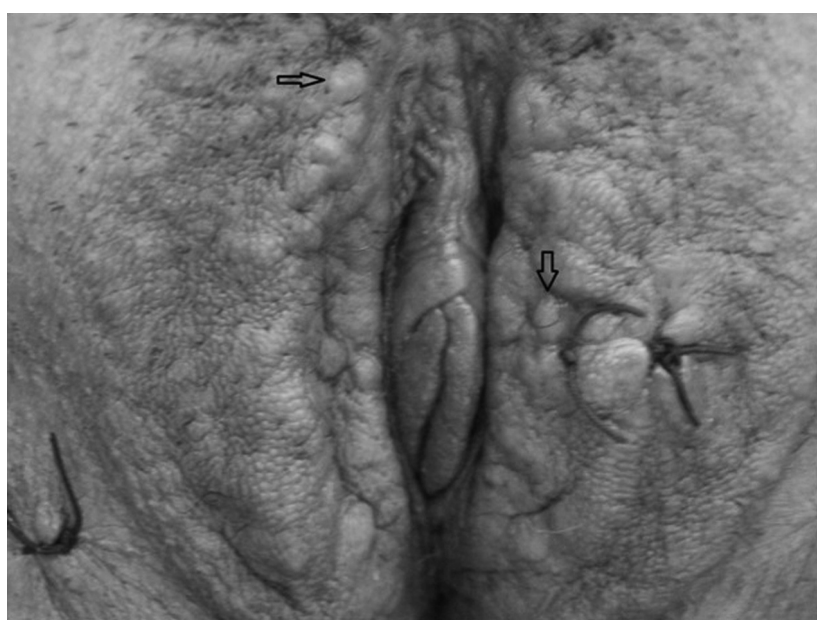

Figure 1. The appearance of vulvar syringoma (black arrows).

and left labia majors (Figure 1). She did not complain about any exacerbation of the pruritus. There was no history of similar lesions elsewhere or in any other family members. The result of the systemic examination was also unremarkable. Written informed consent was obtained from the patient for publication of this brief case report and the accompanying images. The patient underwent a total abdominal hysterectomy, transobturator tape sling insertion and vulvar biopsy.

The histological examination of the hysterectomy specimen was unremarkable but the vulvar lesion was determined to be syringoma (Figure 2 and 3). Microscopic examination of the vulvar lesion showed a well-defined nodular proliferation of the ducts lined with keratinized epithelial cells in the upper dermis; some of the ducts had comma-like tails which created a tadpole like appearance. The surrounding stroma included collagen and some ducts were filled with homogenous eosinophilic material with the appearance of tubular structures, cords and solid cell islands.

The vulvar lesion was diagnosed as an isolated, benign, asymptomatic vulvar syringoma and no treatment was recommended to the patient.

\section{Discussion}

Syringomas are most common in females, presenting during adolescence, and most commonly appearing on the face ${ }^{5}$. Isolated vulvar syringomas area are very rare. Genital syringomas have commonly been described in association with extra genital lesions ${ }^{6}$.

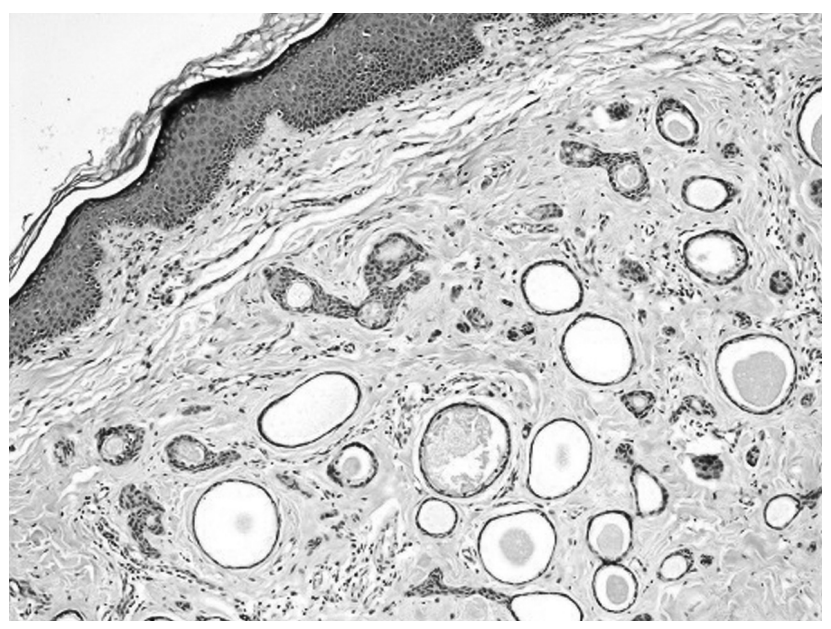

Figure 2. Well defined nodular proliferation of the ducts in the dermis (H\&EX40).

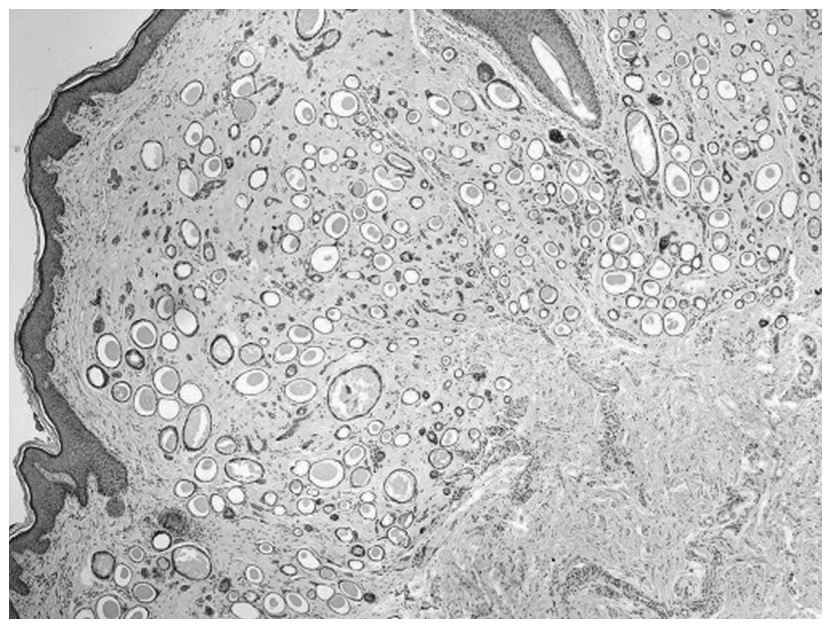

Figure 3. Epithelial cell groups with dilated tubules, cords or solid appearance, some of which are tadpole shaped. The cell groups are surrounded by collagenous stroma (H\&EX100).

Thus, examination of the whole body is essential when a suspected syringoma is found in the vulvar region. In a review of 18 cases, two other clinical appearances of vulvar syringoma have been described: milium-like whitish cystic papules and lichenoid papules².

The diagnosis of the syringomas must be confirmed by a histopathology examination. Some of the ducts possess a small comma like tail of epithelial cells giving the appearance of a tadpole. Solid nests and strands of cells with basaloid appearance may be present.

Syringoma usually presents as multiple discrete or grouped, small, firm, and flesh colored papules. Histologically, syringomas are characterized by numerous dermal tumors composed of multiple small ducts 
of an eccrine type, usually lined by two layers of cuboidal epithelium ${ }^{2}$. Our case showed the typical clinical and histological findings of vulvar syringoma.

Asymptomatic lesions are usually not detected by the clinicians due to their clinical characteristics. However, vulvar syringomas are usually noticed during routine gynecological examination in case where they cause severe pruritus at the vulvar region. The vulvar syringoma lesions should be differentiated from flesh colored or non-pigmented papules and nodules of the vulva including sebaceous glands and hyperplasia, vestibular papillae, acrochordon, cysts, lipomas, genital warts, molluscum contagiosum, and lymphedema. The differential diagnosis for vulvar syringoma is broad and the clinical and histopathological examination may exclude such diseases as epidermoid cysts, steatocystoma multiplex, Fox-Fordyce disease, lymphangioma circumscriptum, angiokeratoma, allergic and irritant contact dermatitis ${ }^{7}$.

Treatment is not necessary in asymptomatic lesions. Low to mild potent topical corticosteroids may be prescribed in cases of severe itching. In some patients, topical atropine or tretinoin provides symptomatic relief ${ }^{8,9}$. Most of the symptomatic patients do not improve following medical therapy and topical steroids, thus surgery is required. Surgical treatment may include excision, cryotherapy, carbon dioxide laser ablation, and electro-desiccation. Excision or ablation is curative. We did not recommend any treatment in our case.

In conclusion, syringoma may be seen on vulva without extragenital involvement during perimenopausal period. Syringoma should be seriously considered in the differential diagnosis of any multicentric, symmetrically flesh colored or non-pigmented papules and nodules of the vulva with or without pruritus. The differential diagnosis of this benign entity is important to prevent the use of unnecessary medications and/or surgery.

\section{Conflict of Interest}

No conflict of interest is declared by the authors.

\section{References}

1. Miranda JJ, Shahabi S, Salih S, et al. Vulvar syringoma, report of a case and review of the literature. Yale J Biol Med 2002;75:207-10.

2. Huang YH, Chuang YH, Kuo TT, et al. Vulvar syringoma: a clinicopathologic and immunohistologic study of 18 patients and results of treatment. J Am Acad Dermatol 2003;48:735-9.

3. Dereli T, Turk BG, Kazandi AC. Syringomas of the vulva. Int J Gynaecol Obstet 2007;99:65-6.

4. Hashimoto K, Gross BG, Lever WF. Syringoma. Histochemical and electronmicroscopic studies. J Invest Dermatol 1966;46:150-66.

5. Young AW Jr, Herman EW, Tovell HM. Syringoma of the vulva: incidence, diagnosis, and cause of pruritus. Obstet Gynecol 1980;55:515-8

6. Carneiro SJ, Gardner HL, Knox JM. Syringoma of the vulva. Arch Dermatol 1971;103:494-6.

7. Kavala M, Can B, Zindanci I, et al. Vulvar pruritus caused by syringoma of the vulva. Int J Dermatol 2008;47:831-2.

8. Sánchez TS, Daudén E, Casas AP, et al. Eruptive pruritic syringomas: treatment with topical atropine. J Am Acad Dermatol 2001;44:148-9.

9. Gómez MI, Pérez B, Azaña JM, et al. Eruptive syringoma: treatment with topical tretinoin. Dermatology 1994;189:105-6. 